\title{
Process of sanitation of certified free properties of brucellosis and tuberculosis in the State of São Paulo
}

\author{
Processo de saneamento das propriedades certificadas como livres de brucelose e \\ tuberculose no Estado de São Paulo
}

CARRARO, Paulo Eduardo ${ }^{*} ;$ BÜRGER, Karina Paes ${ }^{1}$

${ }^{1}$ Universidade Estadual Paulista, Faculdade de Ciências Agrárias e Veterinárias, Departamento de Medicina Veterinária Preventiva e Reprodução Animal, Laboratório de Saúde Pública Veterinária, Jaboticabal, São Paulo, Brasil.

*Endereço para correspondência: ducarrarovet@ hotmail.com

\section{SUMMARY}

The aim of this study was to analyze the sanitation process of the properties certified as free of brucellosis and tuberculosis in the State of São Paulo. However, 14 properties with free certification, between the years 2001 and 2016, were identified and analyzed. The municipalities of the properties were geoprocessed on the map of the state livestock circuit. Through descriptive statistics, a semi-structured questionnaire was evaluated with questions related to the profile of properties (characteristics of the owner, property, production and questions related to human, animal and environmental health) and to the sanitation process. The results showed that, in the state of São Paulo, the 14 certified properties free of brucellosis and tuberculosis were not uniformly distributed, it had herds with 90 to 500 animals, monthly veterinary assistance and milk production was technified with medium or large production capacity milk daily. The owners had an average age of 63,92.8\% (13/14) of them with a higher education level and found difficulties to obtain and maintain the certificate. These properties, even in the process of sanitation, had reinfection in the herd, evidencing the complexity in combating the diseases and the need for more joint actions among the whole community.

KEYWORDS: control, eradication, health program, milk, zoonosis

\section{RESUMO}

O objetivo deste trabalho foi analisar o processo de saneamento das propriedades certificadas como livres de brucelose e tuberculose do Estado de São Paulo. Para tanto, 14 propriedades com certificação livre, entre os anos de 2001 e 2016, foram identificadas e analisadas. Os municípios das propriedades foram geoprocessados no mapa dos circuitos pecuários do Estado. Por meio da estatística descritiva, avaliou-se um questionário semiestruturado com questões relativas ao perfil das propriedades (características do proprietário, da propriedade, da produção e perguntas relacionadas à saúde humana, animal e ambiental) e ao processo de saneamento. Os resultados evidenciaram que no Estado de São Paulo as 14 propriedades certificadas livres de brucelose e tuberculose não se distribuíram uniformemente, possuíam rebanhos com 90 a 500 animais, tendo assistência veterinária mensal, e a produção 
leiteira era tecnificada, com capacidade média ou grande de produção diária de leite. Os proprietários tinham em média 63 anos de idade, 92,8\% (13/14) deles com nível superior de escolaridade e encontraram dificuldades para obter e manter o certificado. Essas propriedades mesmo estando em processo de saneamento tiveram reinfecção no rebanho, evidenciando a complexidade em combater as enfermidades e a necessidade de mais ações conjuntas entre toda a comunidade.

PALAVRAS-CHAVE: controle, erradicação, leite, programa sanitário, zoonoses to evaluate the sanitation process on properties that were certified as free of brucellosis and tuberculosis belonging to the PECEBT of the State of São Paulo. The data obtained by the CDA regarding the state program and the properties certified as free, until then, had only been analyzed and related in a generic way.

Thus, the aim of this study was to analyze the sanitation process of properties certified as free of brucellosis and animal tuberculosis in the State of São Paulo, providing subsidies for the strengthening and evolution of the state program.

\section{INTRODUCTION}

MATERIAL AND METHODS

In the milk production chain, bovine brucellosis and tuberculosis highlights for health losses and economi nature, also causing problems for public health (VALENTE et al., 2011).

In Brazil, as a consequence of the losses caused by both zoonoses, the Ministry of Agriculture, Livestock and Supply (MAPA) created the National Program for Control and Eradication of Animal Brucellosis and Tuberculosis (PNCEBT) in 2001. The State of São Paulo joined the PNCEBT through the State Program for the Control and Eradication of Brucellosis and Tuberculosis (PECEBT) of the Agricultural and Livestock Defense Coordination (CDA). The PECEBT was adequate for the Federative Unit (UF), but not altered (BRAZIL, 2017). The purpose of the national program it was to decrease, these properties obtained the heifers between three and eight months of age against brucellosis and control of animal traffic. The voluntary measures consist of a certification of free of brucellosis and/or tuberculosis (BRAZIL, 2017).

Studies have been carried out to evaluate the cost-benefit of free ownership certification in other States (LEITE, 2012; LÔBO, 2008), however, to date, no studies have been conducted

The present study was carried out in collaboration between the Department of Preventive Veterinary Medicine and Animal Reproduction (DMVPRA) of FCAV / UNESP / Jaboticabal and CDA. The research was divided into two stages, the first was the identification and location of the certified properties free of brucellosis and tuberculosis in the State of São Paulo, followed by the characterization of these properties for analysis and evaluation of the activities carried out during the sanitation process. The analyzed data contains information from the year 2001 to 2016 , decreatse prevalepteg and infejdences of thise zoonoses for era PNCEBT for the year 2001.

Information from PECEBT, obtained through the computerized Animal and Plant Protection Management (GEDAVE) system of CDA, were used to identify and locate the certified properties free of brucellosis and tuberculosis in the State of São Paulo. GEDAVE controls the data of the state program, such as the registration of all 
properties with agricultural activity and the movement of animals by the issuance and receipt of the Animal Transit Guides (GTA).

A form has been completed for each certified property, which includes information about the property and activities developed in it, spatial location of the municipality and veterinarian responsible for sanitation. The tool to enable the geoprocessing of the municipalities where the certified properties are located was the Map Info Professional (version 7.5). The map layer used was the livestock circuit of the State of São Paulo, which is divided into seven livestock circuits.

The profile of the certified properties was characterized by a semi-structured questionnaire that was developed and applied to owners and authorized veterinarians and officials, containing information about the characteristics of the owner, property, type of production, human health, animal health and environmental health, besides development of the PECEBT activities. The application of these questionnaires was carried out between the years 2015 and 2016.

The information related to the properties profile was answered by owners or authorized veterinarians. The information related to the sanitation process to obtain certification was answered by owners or qualified veterinarians or officials. Thus, data from the diagnostic tests for brucellosis and tuberculosis, vaccination against brucellosis, animal transit, the year of certification, the time to obtain certification and the destination of the reactive animals were obtained.
For the analysis of these data, we used the descriptive statistics for categorical variables and recategorized continuous variables, observing the absolute and relative frequencies. Besides, the average of some continuous variables was calculated.

\section{RESULTS AND DISCUSSION}

According to the records contained in CDA's GEDAVE, in the year 2016, there were 18 certified properties, but four owners did not agree to participate in the study, totaling 14 certified properties free of brucellosis and tuberculosis in the State of São Paulo that contributed the present research.

Certified properties that did not participate in the study belonged to the municipalities of Engenheiro Coelho, from the Agricultural and Livestock Defense Office (EDA) of Mogi Mirim, Itatiba (EDA of Campinas), Pedregulho (EDA of Franca) and Buritama (EDA of General Salgado). The fact that they have similarities to the properties participating in this study, as the production profile as in the sanitation process, it did not interfere in the results of the present study.

The analyzed farms were represented by their municipalities on the geoprocessed map, containing information from their respective EDAs and the year of certification (Figure 1). Thus, it was observed that they were mainly distributed in the northeastern region of the State of São Paulo (circuit 4). 


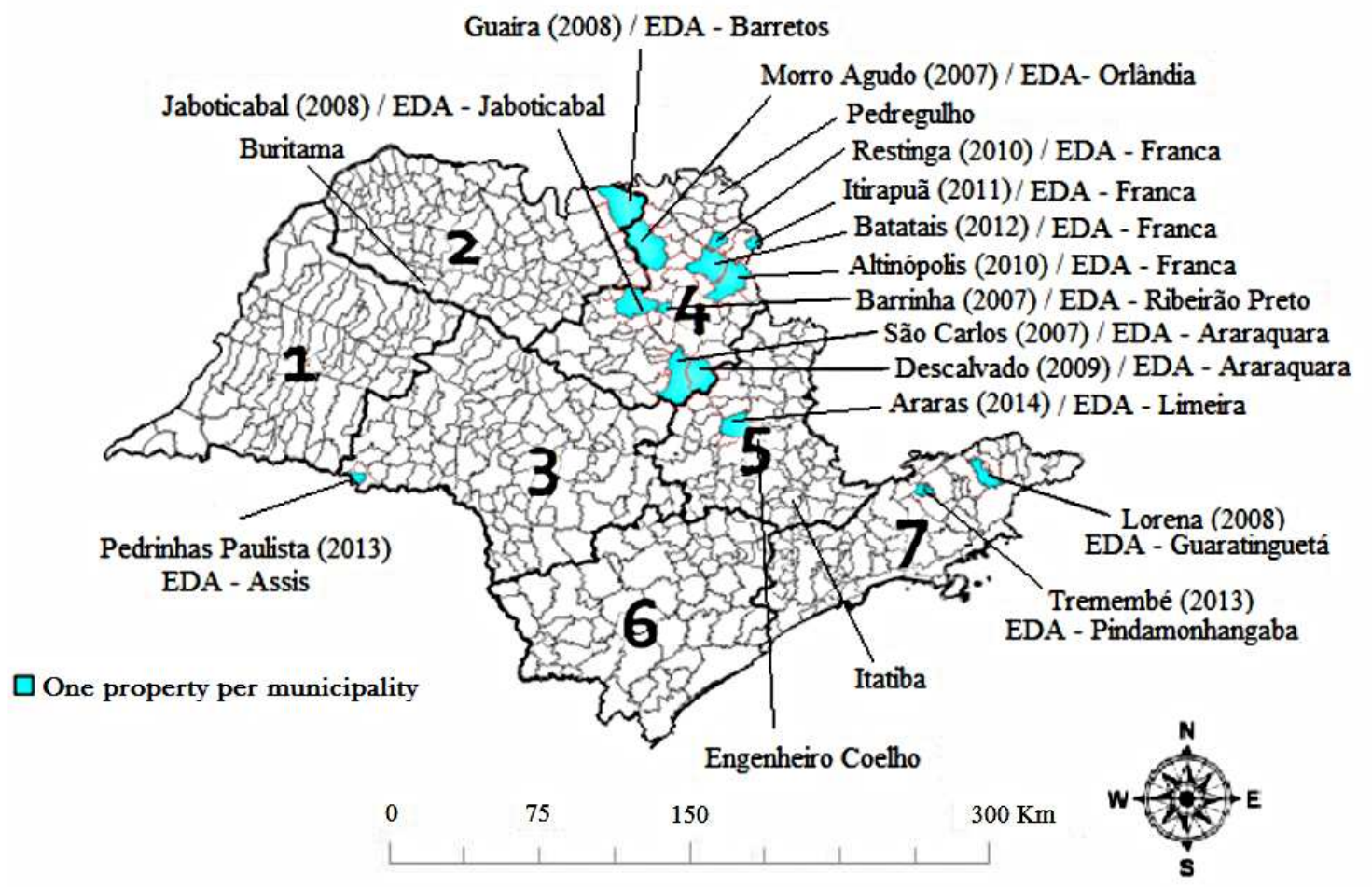

Figure 1. Spatial distribution of the municipalities of the certified properties according to the livestock circuit, the year of certification of free brucellosis and tuberculosis and their respective Agricultural Defense Offices (EDAs). State of São Paulo, 2018

In this region there were microregions with the highest milk production in the country (OVIEDO-PASTRANA et al., 2016; FERREIRA NETO et al., 2016) and, as a consequence, there was more stimulation by industries for the properties with higher milk production to join the PECEBT. Combined with the producer's interest in participating in the program, such facts justify the higher concentration of certified properties in this circuit.

For certified farm owners, they usually were 63 years old between 49-86 years, of which $50 \%(7 / 14)$ were under 57 years of age. The average age of milk producers in several regions of Brazil is similar to that found in this study. According to Rocha Júnior et al. (2014), milk producers in the State of Rio Grande do Sul had an average of 49 years and those of Minas Gerais 52 years.

The age of the producer reflects his experience in the activity, his ability to deal with new technologies and to understand new market requirements. In addition, schooling could influence these factors, since $92.8 \%$ (13/14) of the owners had a higher education level.

This situation was important in the adhesion of the properties to the PECEBT, because of the higher level of the people education, the better the understanding of the problems that involve them. According to Teixeira \& Costa (2011), education is important for determining the risk of zoonotic incidence, given its direct correlation with the level of income and the level of information on forms of disease prevention. 
For the area size of the properties, it was observed a mean of 434.8 ha between 4 and 2,000 ha. Specifically, $36 \%(5 / 14)$ of the properties between 4 and 50 ha, $14 \%(2 / 14)$ between 51 and 100 ha, 29\% (4/14) between 101 and 500 ha, $7 \%(1 / 14)$ between 501 and 1,000 ha and $14 \%(2 / 14)$ with more than 1,000 ha. The main economic activity was the dairy farming with agriculture, seen in $71 \%(10 / 14)$ of the farms, of which $60 \%(6 / 10)$ produced sugar cane, a fact that could justify the large areas of these farms.

The size of the cattle herd varied between 21 and 3,845 animals, however half of the properties had between 90 and 500 animals and only 14\% (2/14) more than 3,000 animals. Regarding milk production, 50\% (7/14) of the farms had daily average production capacity (between 300 and 900 liters), $43 \%(6 / 14)$ high production (greater than 900 liters) and only one farm, 7\% $(1 / 14)$, that was considered low production (between 150 and 299 liters).

The milking was performed only by mechanical milking machine. In 13 $(92.8 \%)$ dairy farms were grown dairy products, and only $21 \%$ (3/14) of the production of dairy products were carried out pasteurization. In this context, even though there are few certified properties, such production characteristics differ from those of most dairy farms in the State of São Paulo. According to Rosolen (2006), the state had about 31,200 milk producers, with a herd of approximately 10 million animals (BUENO, 2015).

Given this scenario, a production with less than 100 liters of milk per day prevailed, and the medium to high milk production profile with a technified system was observed in the minority of state properties. It was predominant crossbreed bovine, the mechanical milking was used by $46.6 \%$ of the producers and $60.7 \%$ of them did not receive technical assistance (ROSOLEN, 2006).

This difference occurred because most rural producers in the state of São Paulo, who had low schooling and low production income, had difficulties in implementing a technological system and sanitary management, as evidenced by Maia et al. (2013) studies. According to Rocha Júnior et al. (2014), such producers only increased the production stratum and improved the type of production system used as they obtained an adequate production management.

The certified farms belonged to the group with medium to high milk production, because the producers, who certified their properties were working on dairy farming with herds containing many animals and with investment in technology. As a result, the production was intensified and better production financial returns were obtained.

In this case, the contracting of the veterinary medical service was an important consensus among all owners, since at least once a month qualified veterinarians assisted in different management of the property. This data could highlight the importance of the veterinarian as a technical responsible for dairy farms, since it makes possible to maximize production and minimize health risks (SANTOS \& CARVALHO, 2013), especially in properties that are in the process of sanitation to obtain certification.

In relation to the state program, through GEDAVE, it was possible to observe that it began in its initial stages, establishing standards and conforming to the requirements for certification such as the availability of qualified veterinarians, institutions that would 
offer a course for the qualification of these professionals, accredited laboratories, acquisition of antigens and tuberculins and dissemination to milk producers.

Thus, the first certification of free adhesion of brucellosis and tuberculosis in the State of São Paulo occurred in 2007, that is, six years after the creation of the PNCEBT. Adhesions to the state program and certifications of free properties were observed after this period in subsequent years.

Nevertheless, few properties have adhered to the certification process in the state program of the State of São Paulo until the present moment, since, although the certification consists of a voluntary action, it involves a cost and this fact increases when allied to the ignorance of the milk producers on the health program and the non-requirement of certification by industries that benefit milk.

Current legislation (BRAZIL, 2011) establishes that the dairy properties that commercialize milk for the industry are all certified free of brucellosis and tuberculosis, but this does not occur in the majority of milk properties in the State of São Paulo.

Leite (2012) concluded in his research that this problem could be mitigated if the industries demanded the certification of all their suppliers, in order to exploit it in their packing, adding value to their products. Or, if larger companies would stimulate the certification of certain properties, aiming exclusively to meet more demanding of the external markets.

According to the same author, this has occurred in countries such as the United States of America, New Zealand and Australia, where tuberculosis eradication programs were successful and all of them had the participation and encouragement of the private sector and the involvement of milk producers in different levels of production.

In relation to the cost of sanitation, according to Lôbo (2008), the effect of the additional payment by the industry was enhanced by the level of milk production, but when there was no subsidy bonus to the sanitary condition reached, it was not advantageous for the producers to join the certification, since the lack of economic stimuli did not justify the costs of the process. This fact corroborates with the results of the present research since most of the certified properties had medium to high milk production capacity and received subsidies from the industries that purchased it.

Therefore, raising awareness among milk producers about the benefits of sanitation being greater than the costs of the process may be a health education strategy, especially in circumstances where producers do not have knowledge about PNCEBT. A fact verified by Pereira \& Dutra (2012), who interviewed 21 rural producers in the state of São Paulo and observed that $47.6 \% \quad(10 / 21)$ performed the serological survey for brucellosis, but no producer knew the PNCEBT and the certification of property free from brucellosis and tuberculosis.

An activity of great value to the Official Veterinary Service (SVO) that can contribute to increasing the participation of milk producers in health programs, including PECEBT, may be the intensification of health education. Health education is an essential component of disease control and this approach can be integrated into health programs. The information is not limited to the damages caused in the zootechnical indices, it also includes the awareness of action strategies, the 
zoonotic nature of the diseases and the good hygienic-sanitary practices.

According to Sarti and Rajshekhar (2003), health education, as in other interventions has limitations when viewed only as an autonomous approach, since improvements in knowledge do not automatically translate into behavioral changes and practices necessary to impact the occurrence of the disease.

The educational message that needs to be directed to the community requires a multidisciplinary intervention team with a unique health strategy approach. This concept is linked to the prevention and control of infectious diseases at the interface agent, host and environment, so that animal health, human health and environmental health are inseparable. However, this is still a challenge in many countries as in Brazil.

According to Gabriël et al. (2017), when involving zoonotic diseases, changes in risk behavior are expected only when people realize that their attitudes are causing health risks, economic benefits are expected, or cultural barriers are addressed.

In the case of bovine brucellosis and tuberculosis, the risk factors that influence are not perceived as important by the rural producers, due to the lack of knowledge about the diseases, the long incubation period in the animal and the human being and the lack of perception of economic losses due to the decrease in milk production.

In this study, it was observed that even owners with access to education had difficulties in carrying out the sanitation of their properties, showing that interventions to combat diseases need to be integrated into health education.

At the time of data collection of this research, according to PECEBT, the properties were able to receive the certificate during a minimum period of nine months of sanitation, when they obtained three consecutive negative tests in all the animals of the herd.

In this context, two properties (14\%) were certified approximately two years after the beginning of sanitation (Table 1), due to the presence of reactive animals in the herd and/or possible financial problems. In this way, the examinations were postponed, and the time to obtain the first certification varied. In this case, the average time to get it was 12 months.

Most farms have been sanitized with the time period close to the minimum required. As a result, most sanitation processes were faster and less costly. In addition, all owners opted for the annual renewal of certification over the years, because of the commercial value of their products and property, for adding value to the sale of male and female reproducers, and for being able to issue the GTA faster.

Table 1. Period of time to obtain certification of free properties of brucellosis and tuberculosis of the State of São Paulo. State of São Paulo, 2018

\begin{tabular}{ccc}
\hline Time (in months) & Absolute frequency & Relative frequency \\
\hline$\geq 9 \leq 10$ & 7 & $50 \%$ \\
$\geq 11 \leq 13$ & 5 & $36 \%$ \\
$\geq 14 \leq 26$ & 1 & $7 \%$ \\
$\geq 27 \leq 36$ & 1 & $7 \%$ \\
\hline
\end{tabular}


As shown in Table 2, the difficulties are noted in the sanitation process, during certification and renewal, since 50\%
$(7 / 14)$ of the properties were foci at some point in the process.

Table 2. Cases of focus at the stage of certification and renewal of properties free of brucellosis and tuberculosis of the State of São Paulo, between the years of 2001 and 2016. State of São Paulo, 2018

\begin{tabular}{ccccc}
\hline \multirow{2}{*}{ Property } & \multicolumn{2}{c}{ Certification process } & \multicolumn{2}{c}{ Renewal process } \\
\cline { 2 - 5 } & $\begin{array}{c}\text { Absolute } \\
\text { frequency }\end{array}$ & $\begin{array}{c}\text { Relative } \\
\text { frequency }\end{array}$ & $\begin{array}{c}\text { Absolute } \\
\text { frequency }\end{array}$ & $\begin{array}{c}\text { Relative } \\
\text { frequency }\end{array}$ \\
\cline { 2 - 5 } $\begin{array}{c}\text { disease-free } \\
\text { disease-focused }\end{array}$ & 2 & $85.70 \%$ & 9 & $64.30 \%$ \\
\hline $\begin{array}{c}\text { Number of reactant } \\
\text { animals in properties that } \\
\text { were foci }\end{array}$ & $14.30 \%$ & 5 & $35.70 \%$ \\
\hline $\begin{array}{c}\text { Positive for brucellosis } \\
\text { Positive for tuberculosis }\end{array}$ & 1 & $10 \%$ & 3 & \\
Inconclusive for & 4 & $40 \%$ & 1 & $16.70 \%$ \\
tuberculosis & 5 & $50 \%$ & 0 & $0 \%$ \\
Inconclusive for brucellosis & 0 & $0 \%$ & 2 & $33.30 \%$ \\
Total of animals & 10 & $100 \%$ & 6 & $100 \%$ \\
\hline
\end{tabular}

During the third stage of the tests for the first certification, four $(40 \%)$ of the animals reactive to the diagnostic tests were positive for tuberculosis in both properties, and one $(10 \%)$ was positive for brucellosis in a single property. Nevertheless, in the process of renewal, the difficulties in maintaining the sanitary condition of the herd occurred in $35.70 \%(5 / 14)$ of the farms. Thus, among the six reactive animals, three $(50 \%)$ were positive for brucellosis, coming from three properties and one was positive for tuberculosis in a property.

The livestock circuits that had properties with reactive animals were circuits 2 and 4 . Thus, $85.70 \%(6 / 7)$ of the foci occurred in the livestock circuit 4 and $14.30 \%(1 / 7)$ in the livestock circuit 2 .

In cases of positive reactive animals, the owners opted for euthanasia on the property, under the supervision of the Official Inspection Service, with a frequency of $85.71 \%(6 / 7)$. The option of sanitary slaughtering was observed in only one property. When the disposal of the animals occurred on the property, all owners chose to bury the animal in the trench and cover it with virgin lime.

Thus, they were in accordance with the current legislation, besides contributing to the non-contamination of the environment. In this context, however, it is perceived that the properties were at risk of reinfections with both zoonoses, even though they were certified.

This has happened because the cause of bovine tuberculosis in milk farms is multifactorial with complex interactions of herd management practices, causing the microorganisms to re-circulate on a freehold. Thus, the simple fact of having milk production has already 
been described as a risk factor, as observed in the study by Dias et al. (2016). The main risk factor for brucellosis was increased herd size due to the easiness in the transmission of the agent caused by the greater frequency of animal replacement (FERREIRA NETO et al., 2016).

The proximity between the dairy properties that were in the process of sanitation and others that were not could be an aggravating factor. According to Ferreira Neto et al. (2016), among the seven circuits producers of the State of São Paulo, those who had higher incidence of diseases, in relation to brucellosis, were the circuits 2, 4 and 6 , and for tuberculosis, the circuits 2, 4, 5 and 7.

These results corroborate with the present study, since the properties with problems in the sanitation process were mainly in region 4. Besides, the circuits with the highest occurrence of bovine tuberculosis in the State of São Paulo is border by producing regions 5, 6 and 7 of the State of Minas Gerais. In this case, studies have already detected prevalence of foci for brucellosis in Minas Gerais cattle ranches 5, 6 and 7 (GONÇALVES et al., 2009).

Through these studies, it is evident that the vaccination of the herd against brucellosis is of utmost importance and therefore, is mandatory in most states. This practice combined with the new national program legislation where producers can only supply milk to industries by proving their regularity, will take action against brucellosis more effectively.

Gonçalves et al. (2009) evidenced the importance of vaccination since they concluded that the properties that vaccinated the bovine females have less probability to have diseased animals than those that did not perform this obligatory practice. In the present study, approximately 8,500 bovine females aged between three and eight months were vaccinated with the B19 vaccine and no animals were vaccinated with the RB51 vaccine.

This result is similar to that found by Ferreira Neto et al. (2016) since they observed low commercialization of RB51 throughout the national territory. The authors concluded that this was due to the lack of interest of the farmers due to the result of an inefficient dissemination of information on the role of the RB51 vaccine in the context of the PNCEBT.

Despite the lack of use of the RB51 vaccine by the properties analyzed, its use is important for the actions of control and eradication of brucellosis, since it does not cause a false positive result in the diagnosis of brucellosis, especially in early animals, and avoids the elimination of animals without infection and the costs of losing the animal. Therefore, at the present time, the PNCEBT allowed its use in bovine females in order to be used during the vaccination campaigns.

As expected, interstate transit control of animals destined for reproduction and participation in agglomerations was verified in all properties analyzed, through the issuance of GTA. Because the animals are from certified properties, it is easier to emit them.

This strategy is a considerable part of the state program, since the more certified properties, the easier it will be to control bovine transit, thus being an important and effective action to control brucellosis and bovine tuberculosis in the State.

The actions foreseen by the PECEBT, such as vaccination against brucellosis, control of animal traffic, diagnosis and slaughter of the reactive animals, are 
important for the control of the diseases studied, but when carried out in isolation do not guarantee the health of the herd. Therefore, the presence of a large number of certified free properties in the State is important.

The fact that the epidemiology of bovine brucellosis and tuberculosis is complex, has made it difficult to effectively control the few properties that have adhered to the certification process. Since it was only possible after a long period of sanitation due to the difficulties of the program itself and the epidemiological character of the diseases.

Consequently, actions to combat these diseases need to be encouraged in all livestock circuits in the State of São Paulo. Thus, it is evident the need for joint actions between SVO and the private sector, in addition to the adequate implementation of a state health education project.

\section{ACKNOWLEDGMENTS}

To the Coordination of Agricultural Defense of Secretariat of Agriculture and Supply of the State of São Paulo, to qualified veterinarians, certified property owners and to National Council for the Improvement of Higher Education (CAPES).

\section{REFERENCES}

BRAZIL. Ministry of Agriculture, Livestock and Supply. Normative Instruction $\mathrm{n}^{\circ} .10$ of March 3, 2017. Technical Regulation of the National Program for the Control and Eradication of Animal Brucellosis and of
Tuberculosis - PNCEBT and the Classification of Units of the Federation according to the degree of risk for the diseases brucellosis and tuberculosis, as well as the definition of animal health protection procedures to be adopted according to the classification. Official Journal of the Union, Brasília, June 20, Section 1, p.116, 2017.

BRAZIL. Ministry of Agriculture, Livestock and Supply. Normative Instruction $\mathrm{n}^{\circ}$. 62, of december 29, 2011. Official Journal of the Union, Brasilia, Section 1, p.119, 2011.

BUENO, C.R.F. Queda no rebanho e na produção de leite no Estado de São Paulo, 2005 a 2014. Análises e Indicadores do Agronegócio, v.10, n.6, 2015.

DIAS, R.A.; ULLOA-STANOJLOVIC, F.M.; BELCHIOR, A.P.C.; FERREIRA, R.S.; GONÇALVES, R.C.; AGUIAR, R.S.C.B.; SOUSA, P.R.; SANTOS, A.M.A.; AMAKU, M.; FERREIRA, F.; TELLES, E.O.; GRISIFILHO, J.H.H.; GONÇALVES, V.S.P.; HEINEMANN, M.B.; FERREITA NETO, J.S. Prevalence and risk factors for bovine tuberculosis in the State of São Paulo, Brazil. Semina: Ciências Agrárias, v.37, n.5, p.3673-3683, 2016.

FERREIRA NETO, J.S.; SILVEIRA, G.B.; ROSA, B.M.; GONÇALVES, V.S.P.; GRISI-FILHO, J.H.H.; AMAKU, M.; DIAS, R.A.; FERREIRA, F.; HEINEMANN, M.B.; TELLES, E.O.; LAGE, A.P. Analysis of 15 years of the National Program for the Control and Eradication of Animal Brucellosis and Tuberculosis, Brazil.

Semina: Ciências Agrárias, v.37, n.5, p.3385-3402, 2016. 
GABRIËL, S.; DORNY, P.; MWAPE, K.E.; TREVISAN, C.; BRAAE, U.C.; MAGNUSSEN, P.; THYS, S.; BULAYA, C.; PHIRI, I.K.; SIKASUNGE, C.S.; MAKUNGU, C.; AFONSO, S.; NICOLAU, Q.;

JOHANSEN, M.V. Control of Taenia solium taeniasis/cysticercosis: The best way forward for sub-Saharan Africa?

Acta tropica, v.165, p.252-260, 2017.

GONÇALVES, V.S.P.; DELPHINO, M.K.V.C.; DIAS, R.A.; FERREIRA, F.; AMAKU, M.; FERREIRA NETO, J.S.; PORTO, T.B.; ALVES, C.M.; FIGUEIREDO, V.C.F.; LÔBO, J.R. Situação epidemiológica da brucelose bovina no Estado de Minas Gerais.

Arquivo Brasileiro de Medicina Veterinária e Zootecnia, v.61, p.35-45, 2009.

\section{LEITE, B.M. Aspectos}

epidemiológicos e econômicos da certificação de propriedades leiteiras como livres de brucelose e tuberculose bovina. 2012. 88f. Dissertação (Mestrado em saúde animal) - Faculdade de Agronomia e Medicina Veterinária, Universidade de Brasília, Brasília/DF, 2012.

\section{LÔBO, J.R. Análise custo benefício da} certificação de propriedades livres de tuberculose bovina. 2008. 84f.

Dissertação (Mestrado em

Agronegócios). - Faculdade de Agronomia e Medicina Veterinária, Universidade de Brasília, Brasília/DF, 2008.

MAIA, G.B.S.; PINTO, A.R.; MARQUES, C.Y.T.; ROITMAN, F.B.; LYRA, D.D. Produção leiteira no Brasil. BNDES Setorial, v.2, n.37, p.371-398, 2013.
OVIEDO-PASTRANA, M.E.; OVIEDO-SOCARRÁS, T.J.; HADDAD, J.P.A. Avaliação de uma nova metodologia para a representação da pecuária no Brasil. Arq. Bras. Med. Vet. Zootec., v.68, n.6, p.1681-1689, 2016.

PEREIRA, F.B.; DUTRA, S.

Diagnóstico de situação das práticas de manejo sanitário em sistemas de produção de bovinos de corte.

Veterinária e Zootecnia, v.19, n.4, p.522-530, 2012.

ROCHA JÚNIOR, B.D.; MONTOYA, M.A.; PASQUAL, C.A.; FINAMORE, E.B. O perfil dos produtores de leite, o processo de sucessão e a renda bruta no Rio Grande do Sul: análise do Corede Produção. Teoria e Evidência Econômica, n.42, p.42-66, 2014.

ROSOLEN, J.E. Mapa do leite no Estado de São Paulo. Revista Balde Branco, v.41, n.504, p.39-46, 2006.

SANTOS, T.S; CARVALHO, D.A. Atuação e importância do médico veterinário na cadeia produtiva do leite. Veterinária em Foco, v.10, n.2, p.149158, 2013.

SARTI, E.; RAJSHEKHAR, V. Measures for the prevention and control of Taenia solium taeniosis and cysticercosis. Acta Trop., v.87, p.137143, 2003.

TEIXEIRA, E.C.; COSTA, J.S. O impacto das condições de vida e da educação sobre a incidência de tuberculose no Brasil. Revista de Economia, v.37, n.2, p.106-123, 2011.

VALENTE, L.C.M.; VALE, S.M.L.R.; BRAGA, M.J. Determinantes do Uso de 
Medidas Sanitárias de Controle da Brucelose e Tuberculose Bovina.

Revista de Economia e Sociologia

Rural, v.49, n.1, p.215-232, 2011. 